\title{
Preparation of an $N$-Linked Glycopeptide Containing 6-ThioGlcNAc
}

\author{
Injae Shin, ${ }^{\dagger}$ Sungjin Park, Kwan Soo Kim, Jin Won Cho, ${ }^{*}$ and Dongyeol Lim ${ }^{\ddagger}$
}

\author{
Department of Chemistry and Department of Biologk, Ionsei Chimersitw, Seoul 120-749, Korea \\ ${ }^{\ddagger}$ Deparment of Chemistry: Sejong Lniversitw, Seoul 143-747, Korea \\ Received September 11, 2001
}

Keywords : Carbohỵdrates. Glycopeptides. Glỵcoș̣lations. Chemoselective ligation.

The $O$ - and $N$-glycosylated proteins are expressed in eukaryotic cells as heterogeneous mixtures of glycoforms. namely. proteins possessing heterogeneous carbohydrate moieties and thus their purification from natural sources is difficult. As a consequence. the structural effects of carbohydrates on glycoproteins and biological functions of glycoproteins remain elusive. It has been well-documented that carbohydrates of glycoproteins modulate receptor binding and signaling. and influence the intrinsic properties of protein backbones. resulting in the proper folding of proteins. increased thermal stability and resistance to proteases. Therefore. it is imperative to readily access glycoproteins with well-defined oligosaccharide chains to elucidate their biological functions.

Recently many attempts to introduce carbohydrate moieties into proteins or peptides at a specific position wa nonnative glycosidic linkage in a chemoselective manner have been made. ${ }^{23}$ In an effort to develop a new methodology to prepare homogeneous glycoproteins. we have investigated the chemoselective ligation of carbohydrates containing a maleimide group to peptides or proteins wa a stable thioether linkage. ${ }^{4}$ As part of our ongoing work. we prepared thiol-containing $N$-acetylglucosaminyl serine (1) as a building block for synthesis of $N$-linked glycopeptides bearing 6ThioGlcNAc. that can be further glycosylated with thiolreactive carbohydrates at $6-\mathrm{SH}$ site through a disulfide bond as shown in Figure 1. The $N$-linked glycosylation on glycoproteins is catalyzed by oligosaccharyl transferase during co-translational process. Carbohydrate moieties in $\mathrm{N}$-glycosylated proteins are covalently attached to an asparagines residue in the consensus sequence of Asn-X-Thr/Ser. where $\mathrm{X}$ is any amino acid except proline. and are known to influence the folding of proteins or the stability of the protein backbones.

Sy'nthesis of a protected 6-ThioGlcNAc-Ser monomer (1) was efficiently achieved from $N$-acetỵlglucosamine (2) by

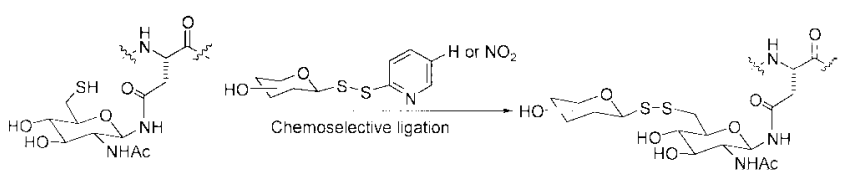

Figure 1

To whon correspondence should be addressed. Tel: $+82-2-$ 2123-2631; Fax: +82-2-364-7050; E-mail: injaeayonsei.ac.kr the reactions delineated in Scheme 1. Peracetylated GlcNAc$\mathrm{N}_{3}$ (3) derived from 2 according to a known procedure ${ }^{6}$ was deacetylated quantitatively under basic conditions. A selective tosylation of a primary alcohol in 4 with 2 equiv of TsCl in pyridine followed by acetylation of the secondary alcohols produced a mono-tosylated azide 5 in $78 \%$ yield. Tosylation of 4 with less than 2 equiv of TsCl furnished the desired product in low yield. It was noted that the progress of tosylation of the primary alcohol in 4 should be carefully monitored by TLC to prevent the bis-tosylation of 4. Substitution of tosyl group by thioacetyl group with potassium thioacetate (KSAc) in the presence of $18-$ crown- 6 at $60^{\circ} \mathrm{C}$ provided a thioacetylated azide 6 in $80 \%$ yield. It is worthwhile to mention that the substitution reaction of tosyl group in the absence of 18 -crown- 6 gave a poor yield $<<30$ $\%$ yield) of 6 as a result of the formation of an unidentified side product. Reduction of 6 and subsequent coupling of the
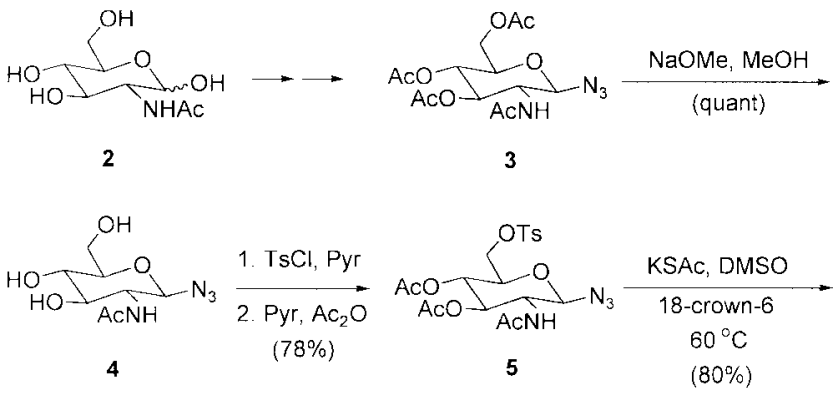

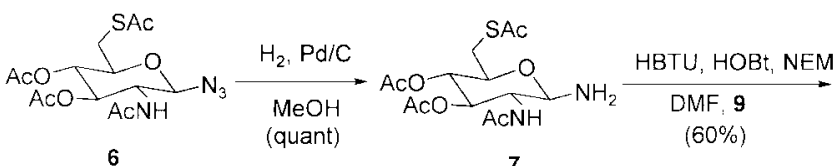
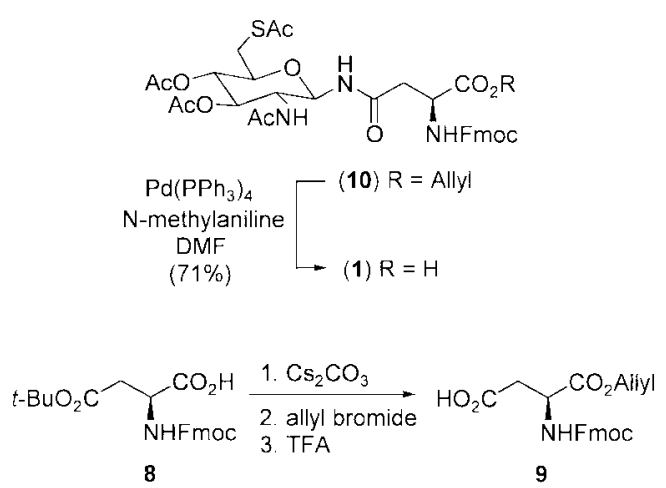

Scheme 1 


\section{Fmoc-Rink amide-PS PEG}

1. $20 \%$ p peridine in DMF

1. 20\% piperidine in DMF
2. Fmoc amino acid. HBTU HOBt, DIEA, $2 \mathrm{hr}$

Fmoc-Glu(tBu)-Thr(tBu)-His(Trt)-Rink amide-PS PEG
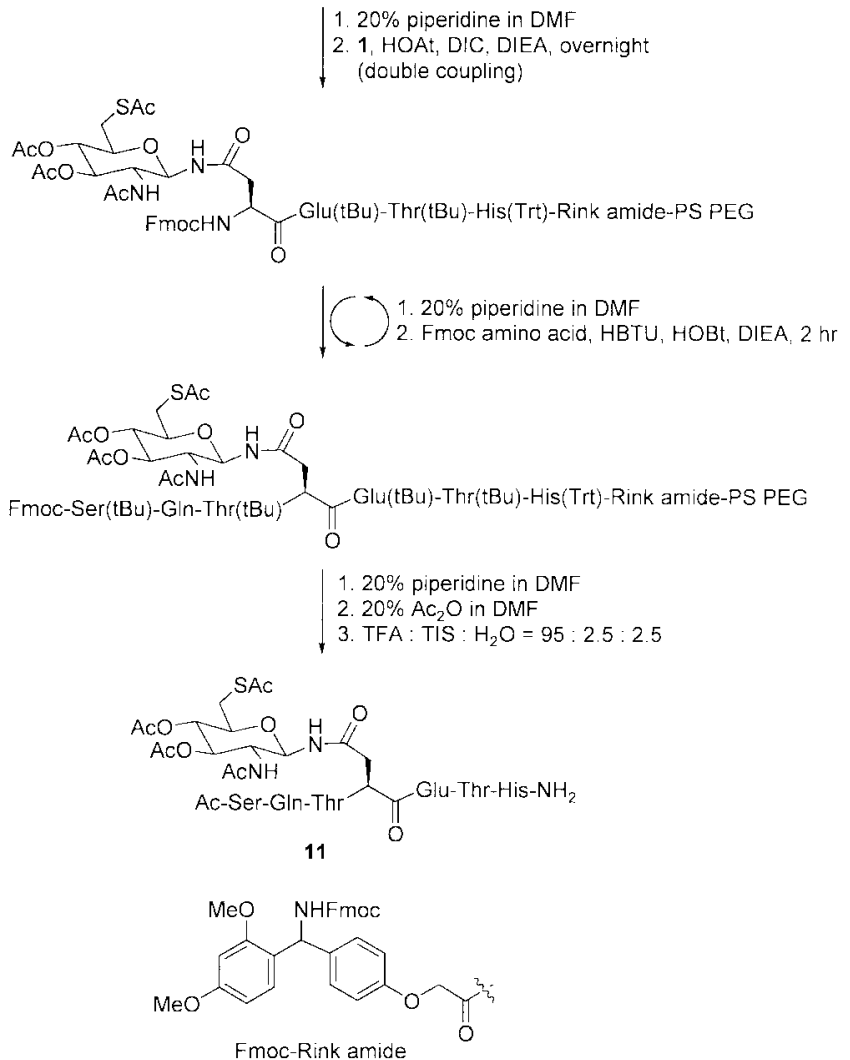

Scheme 2

resultant amine 7 to 9 obtained from Fmoc-Asp(tBu)-OH (8) in three steps ${ }^{7}$ by $O$-benzotriazole- $N, N, N^{\prime} N^{\prime}$-tetramethyluronium-hexafluorophosphate (HBTU), $N$-hydroxybenzotriazole $(\mathrm{HOBt})$ and $N$-ethy lmorpholine (NEM) afforded a glycosylated serine $\mathbf{1 0}$ in $60 \%$ yield. Finally. the allyl group in $\mathbf{1 0}$ was removed using $\mathrm{Pd}\left(\mathrm{PPh}_{3}\right)_{4}$ in the presence of $N$-methylaniline as a hydrogen donor to give the desired monomer 1 in $71 \%$ yield. ${ }^{8}$

Next, we prepared a glycopeptide 11 possessing 6-ThioGlcNAc. The glycopeptide 11 was synthesized on PS-PEG (polystyrene-polyethylene glycol) Rink anide resin on a 0.5 inmol scale using Fmoc-amino acids (Scheme 2). peptide assenbly was performed by a manual peptide synthesis using $\mathrm{HOBt} / \mathrm{HBTU}$-mediated couplings. except for the coupling of 1 . which was carried out by double coupling using the more powerful coupling reagents of DIC/HOAt. ${ }^{10}$ After completion of chain assembly. Fmoc group of $N$ terminus was removed and the exposed $\mathrm{NH}_{2}$ was acetylated. Finally, glycopeptide 11 was cleaved from the solid support by treatment with TFA : triisopropylsilane : $\mathrm{H}_{2} \mathrm{O}(95: 2.5$ : 2.5 ) and characterized by ESI MS. ${ }^{11}$

In sunmary. we developed an efficient synthesis of a thiol-containing $N$-acetylglucosaminyl serine monomer and synthesized the glycopeptide mimetic using a prepared monomer. Further glycosylation of a glycopeptide with thiolreactive carbohydrates after deacetylation is in progress.

Acknowledgment. This work was supported by a grant of the Korea Science and Engineering Foundation (1999-212300-005-5).

\section{References}

1. (a) Dwek. R. A. Chem. Rev 1996. 96.683. (b) Varki. A. Glycobiology 1993.3.97.

2. For reviews (a) Stowell. C. P. Lee. Y. C. Ad: Carbohnd Chent. Biochent 1980. 37. 225. (b) Lemieux. G. A.: Bertozzi. C. R. TIBTECH. $1998,16,506$

3. (a) Davis. N. J: Flitsch. S. L. Tetrahedron Lett. 1991. 32, 6793 (b) Wong, S. Y. C.: Guile, G. R.; Dwek. R. A.: Arsequell. G. Biochent $J$. 1994. 300. 843. (c) Macindce. W. M.: van Oijen. A. H.: Boons. G.-T. Chen. Commm 1998. 847. (d) Davis. B. G.: Maughan. M. A. T.: Green. M. P.: Ullman. A.: Tones. J. B. Tetrohedron.Asymmetry 2000. 11. 245. (e) Rodriguez. E. C.: Winans. K. A.; King. D. S.: Bertozzi, C. R. J. Am. Chem. Soc, 1997. 119. 9905. (f) Marcaurelle, L. A.; Bertozzi, C. R. J. Am. Chem. Soc. 2001. 123. 1587. (g) Andersson1. L.: Stenhagen. G.: Baltzer. L. J. Org. Chent 1998.63. 1366.

4. (a) Shin. I.: Tung. H.-j.: Cho. J. Bull. Korean Chent. Soc. 2000.21. 845. (b) Shin, I.; Jung. H.-j.; Lee. M.-r. Tetrahedron Lett. 2001. 42. 1325 .

5. Imperiali, B.: O'Connor, S. E. Cur: Opin. Chem. Biol. 1999, 3. 643.

6. Tropper. F. D.: Andersson1. F. O.: Braun. S.: Roy. R. Symthesis 1992.618 .

7. (a) Wang. S.-S.: Gisin, B. F.: Winter. D. P.: Makofske, R.: Kulesha. I. D.: Tzougrali. C.: Meienhofer J. J. Org. Chem. 1977, 42. 1286. (b) Holm, B.: Linse. S.; Kihlberg. J. Tertrahedron 1998, 54. 11995.

8. LR FAB MS: caled for $[\mathrm{M}-1]^{-} 700.21$. found 700.2 . ' $\mathrm{H}$ NMR (DMSO) $\delta 8.75(\mathrm{~d} . J=6.4 \mathrm{~Hz} . \mathrm{IH}) .7 .98(\mathrm{~d} . J=7.3 \mathrm{~Hz} .2 \mathrm{H}) .7 .80$ $(\mathrm{d} . J=7.0 \mathrm{~Hz}, 2 \mathrm{H}) .7 .51(\mathrm{t}, J=7.0 \mathrm{~Hz}, 2 \mathrm{H}), 7.42(\mathrm{t}, J=7.0 \mathrm{~Hz}$. $2 \mathrm{H}) .5 .25(\mathrm{t} . J=9.0 \mathrm{~Hz} .1 \mathrm{H}), 5.19(\mathrm{t}, J=9.5 \mathrm{~Hz} .1 \mathrm{H}), 4.8(\mathrm{t}, J=$ $9.3 \mathrm{~Hz} .1 \mathrm{H}), 4.37-4.31(\mathrm{~m}, 4 \mathrm{H}) .3 .82(\mathrm{t}, J=9.97 \mathrm{~Hz} .1 \mathrm{H}) .3 .76(\mathrm{~m}$, $4 \mathrm{H}) .3 .1-3.0(\mathrm{~m} .2 \mathrm{H}) .2 .62$ (s. $3 \mathrm{H}$ ). $1.96(\mathrm{~s} .3 \mathrm{H}) .1 .87$ (s. $3 \mathrm{H}) .1 .70$ (s. 3H). ${ }^{13} \mathrm{C}$ NMR (DMSO) $\delta 194.3 .170 .2 .169 .7$. 169.4. 169.2. 162.2. 155.7. 143.8. 140.6. 127.6. 127.0. 125.2. 120.0. 77.9.73.3. $73.0,70.3 .65 .6 .52 .1,50.7 .46 .6 .37 .5,35.7,30.6 .30 .3,29.4 .22 .5$. $20.4,20.3$

9. Brief procedure for solid phase glycopeptide synthesis: Fmoc amitno acid was manually coupled on PS-PEG Rink amide resin on a $0.5 \mathrm{mmol}$ scale. using 3.0 equiv of amino acid and activation with HBTU (3.0 equiv) and HOBt (3.0 equiv) in the presence of DIEA (3.0 equiv). Incorporation of 6-ThioGleNAc-Ser 1 (2.0 equiv) into the glycopeptide was carried out by double coupling using DIC (3 equiv). HOAt (3 equiv) and DIEA (3 equiv). After removal of the N-teminal Fmoe group of a glycosylated peptide with $20 \%$ piperidine in DMF. the resin-bound peptide was treated with 20\%: $\mathrm{Ac}_{2} \mathrm{O}$ in DMF. Peptide cleavage deprotection was achieved under $95^{\circ} \%$ TFA. $2.5^{\circ} \%$ TIS and $2.5^{\circ} \% \mathrm{H}_{2} \mathrm{O}$ conditions. The crude peptide was precipitated with ether and then purified by preparative RP-HPLC with a gradient of $5-100^{\circ}, \mathrm{CH}_{3} \mathrm{CN}$ in water (0.10 TFA) over $30 \mathrm{~min}$.

10. Carpino. L. A.: El-Faham. A. Tetrohe dron 1999. 55.6813.

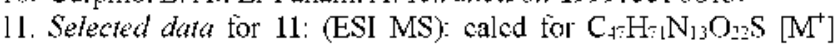
1201. found 1201 